\title{
The Subprime Mortgage Lending Collapse - Should We Have Seen It Coming?
}

Jared E. Hojnacki, Bates White LLC, USA

Richard A. Shick, Canisius College, USA

\begin{abstract}
The subprime mortgage lending crisis and the decline in housing values has profoundly affected the worlds' financial markets. Financial institutions have ceased to exist, others have come under the U.S. government's control, the future survival of others has been threatened and the U.S. government is proposing the greatest financial rescue operation since the Great Depression. Profound changes in the financial markets have occurred and the markets will never be quite the same again. This paper presents the argument that this collapse should have been foreseen by tracing and comparing the development and decline in the subprime auto lending market in the 1990 's to the development and decline of the subprime mortgage lending market. While the effects of the subprime mortgage crisis are greater and farther reaching than those of the subprime auto lending market, there is no question that the similarities are plain to be seen and that the current crisis should come as no surprise.
\end{abstract}

Keywords: subprime mortgage crisis, subprime auto lending crisis

\section{INTRODUCTION}

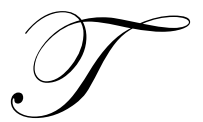

he United States economy is teetering on the brink of a recession, the financial markets are in turmoil, some financial institutions have ceased to exist, leaders of other financial institutions have lost their positions, the Federal Reserve is taking extraordinary measures to keep other financial institutions from bankruptcy, housing values have fallen in many major U.S. markets, loan default rates are growing, and the government is mounting the largest financial rescue since the 1930s with a cost estimated in excess of 1 trillion dollars. While perhaps not the sole cause of all these problems, the collapse of the subprime mortgage market has been a major contributor to the current situation. The question is whether we should have seen this coming. We argue that the similarities between collapse of the subprime auto lending market in the 1990s and the collapse of the subprime mortgage lending market are so great as to suggest that the current situation should not have come as a surprise.

We begin with a general discussion of subprime lending followed by sections tracing the history of both the subprime auto lending and subprime mortgage lending markets. Here we will show many similarities in the conditions leading to the development of the markets, the practices that made them grow at such great rates, the participants that fueled the growth, and the conditions that led to their ultimate collapse. The parallels are startlingly similar and they support the hypothesis that this is just history repeating itself once more.

\section{WHAT IS SUBPRIME LENDING AND WHY DO LENDERS WANT TO PARTICIPATE IN THIS MARKET?}

Subprime borrowers are those individuals who do not meet the traditional standards for loans. Many times these individuals have a weak credit history and are heavily in debt. They are high-risk borrowers, but they are not necessarily going to default on their loans. As one subprime lender put it, "We lend to those who need a second chance, not a last chance." (Three Trends Reshaping Auto Finance pt.1) 
Although precise definitions of subprime borrowers vary among lenders, bank regulators define them by the following characteristics:

- $\quad$ Two or more 30-day delinquencies in the past twelve months;

- $\quad$ one or more 60-day delinquencies in the past 24 months;

- $\quad$ bankruptcy in the previous 5 years;

- $\quad$ a high probability of default as measured by FICO credit score;

- $\quad$ a debt service-to-income ratio of $50 \%$ or more (Bender, p.4)

The prime lending market serves borrowers with a FICO score generally above 720 which has a loss rate of less than 3\%. The midprime market covers credit scores in the 620 to 720 range and has loss ratios under $7 \%$. The subprime market includes those with credit scores below 620 and losses in double digits (Bender, p.4). This subprime market is further segmented by quality, and has grades from A (highest quality) to D (lowest quality) (Hughlett).

Clearly, a major motive for lending in the subprime market is the profit potential. Lenders seek the higher interest rates and fees that go with such loans and mortgage brokers see enormous potential from the origination fees. This motivation was present in both lending crises. However, there is also a more altruistic reason for subprime lending. Without subprime lending there are many borrowers who would be denied access to funds and the assets such as homes and automobiles they buy. Many times these individuals are the victims of an unfortunate turn of events such as the loss of a job or a major uninsured health problem that causes them to default on their loans and ruins their credit ratings. Such individuals need a second chance and they go on to rebuild their credit ratings.

Subprime lending, in and of its self, is not bad. The problems arise when there are not sufficient controls in place to regulate it, when lenders abandon their traditional methods of doing business, when speculators enter the markets, when investors do not understand the market in which they are participating, and when borrowers do not know what they are agreeing to do. Both subprime lending crises illustrate these factors well.

\section{THE SUBPRIME AUTO LENDING CRISIS}

\section{Background}

In the late 1980s and early 1990s several factors combined to spur the growth of the subprime auto lending market. In 1990, just $2.9 \%$ of all new car leases and $17.1 \%$ of all new car purchases were by subprime borrowers. By 1995 , these figures had jumped to $14.3 \%$ of leases and $22.1 \%$ of purchases. In that year alone, it was estimated that $30.5 \%$ of all new vehicles and $52.8 \%$ of all used vehicles sold carried subprime loans (Want a Car? Getting Financing is No Problem). This phenomenal growth was the result of economic conditions, an over-supply of automobiles, and a change in the attitudes of lenders.

As economic conditions deteriorated in the early to mid 1990s, bankruptcies rose. In 1996 alone 1.1 million households declared bankruptcy, five times higher than the levels in 1982 (Three Trends Reshaping Auto Finance pt.1). As a result, the number of subprime borrowers rose dramatically. It became clear that unless many individuals were given subprime loans, they could not purchase automobiles. At the same time, automobile dealers were holding growing inventories of used cars that they could not sell. Faced with these developments, automobile dealers became more willing to welcome the estimated one-half of all automobile buyers who could not buy a vehicle with conventional financing sources (Connelly). Following the dealers' willingness to sell to subprime borrowers, independent lenders and auto manufacturer finance captives rushed in to meet the demand. Lender competition was so great in the 1994-1996 period that interest rates remained relatively stable despite rate increases in other markets (Lawson).

One lender that moved into this market early was Mercury Finance Company. Organized in 1988 as a wholly owned subsidiary of First Illinois Corporation and later spun-off in 1989, Mercury started by providing small loans to "underserved" markets with a focus on U.S. military servicemen. They offered credit to customers lacking 
reasonable credit alternatives, served areas with minimal competition, and decentralized their operations to get closer to the customer. Mercury was phenomenally successful and their loan portfolio grew from $\$ 515$ million in 1991 to more than $\$ 1.2$ billion in 1995 (Long, p.25). Other lenders noticed this success and eagerly joined the market.

The major lenders were independent finance companies, banks, and auto company finance captives such as Ford Motor Credit's Fairlane Credit LLC (Connelly). The banks either created subsidiaries or acquired independent finance companies. This allowed them to deal with the different lending philosophies necessary to service the subprime market, to escape the oversight of bank regulators, and to avoid the reserve requirements (Quinn).

\section{Subprime Auto Lending Market Expands}

The "feeding frenzy" of subprime lending led to many practices designed to increase the volume of loans. Automobile dealers were the interface between the lenders and the borrowers and they were very creative in developing practices to sell cars. For example, they would let customers take cars home while they found a lender (Lawson), and they would advertise heavily using veteran sports celebrities (Quinn). Lenders joined in the activity by sending prospective borrowers pre-approved credit packages to buy the vehicle of their choice (Three Trends Reshaping Auto Finance pt.1). (Note the similarity with pre-approved home mortgage loans.) Some lenders used unethical and illegal practices such as phony down payments, straw buyers, odometer tampering, and phantom options (Lender Foss reflects on a risky business).

Subprime lending could not continue without a supply of funds and Wall Street seized the opportunity. The high returns from these loans with little prior loss experience were an irresistible attraction, and a number of companies were created to service this burgeoning market. Twenty-one IPO's for subprime lenders occurred between 1992 and 1995 and securitization volume increased from \$394 million in 1994 to \$4.5 billion in 1997 (Long, p. 25). The rating agencies did their part to feed the market, providing ratings with little real experience to judge the risk (Long, p. 29).

By $1994-1996$, however, losses from subprime lending began to appear and a destructive trend emerged as lenders increased their loan volume to cover their losses (Long, p. 27). Jim Henry, a writer for Automotive News, described the process as follows: "the vicious cycle went like this: subprime lenders lowered standards to sign up more loans. Lower standards led to higher risk loans and higher losses. That increased the pressure to sign up more loans. And with so much competition, the only way to do that was to lower standards further" (Henry, 1999).

\section{The Auto Lending Market Collapses}

The subprime market began to collapse as news of the losses spread and access to the capital markets closed. Many lenders realized that without access to the capital markets, they could not originate new loans, and without new loans they could not recognize income (Long, p. 28). The downward spiral began. From 1997 to 1999, seven publicly traded subprime auto lenders out of 26 went bankrupt (Henry, 1999). In January 1997, the muchheralded Mercury Finance restated its financials and cut its reported profits by more than 50\%. In February of 1997, the news was worse when Mercury defaulted on $\$ 17$ million in loans and soon thereafter filed for bankruptcy protection (Long, p. 28). The Mercury collapse rippled through the market, and more subprime lenders either filed for bankruptcy or were sold in fire sale transactions at huge discounts (Hughlett). In April 1998, Merrill Lynch estimated that prices of subprime auto finance companies had fallen between $20 \%$ and $30 \%$ in the period from April of 1997 to April of 1998. (Quinn).

The results of this collapse produced a major restructuring in the subprime auto lending market with many lenders either failing or being bought up by competitors. A new subprime lender emerged to set the example for future lending practices. AmeriCredit Finance of Fort Worth Texas introduced discipline into the lending process by using advanced credit scoring models, tightening lending standards, better assessing the underlying credit risk, and more properly pricing the loans (Consumer Finance: The Credit Goes to the Consumer). 
The lessons of the subprime auto market provide a perfect introduction to the current crisis in the subprime mortgage lending market. While there are fundamental differences between the two types of lending, the similarities in how the lending started, the practices that allowed it to grow, the players that were involved, and the conditions that brought the market down are shockingly similar. In retrospect one can only ask why didn't we see this coming and why didn't we know that it could not last?

\section{THE SUBPRIME MORTGAGE LENDING CRISIS}

\section{Background}

Following the Second World War, home ownership increased significantly with the overall rate of ownership rising from $45 \%$ to $65 \%$ in little more than a decade. This boom was largely fueled by the middle class. However, following this initial burst, the percentage of home ownership remained relatively constant for a number of years (Gramlich, p.2). Starting in the mid 1990's home ownership started to grow once again. This change was fueled, in part, by a strong growth in the subprime mortgage lending market, primarily in census tracts where African-Americans were predominant. Originations of subprime mortgages grew from $\$ 65$ billion in 1995 to $\$ 150$ billion in 1998 (Chomsisengphet and Pennington-Cross, pp.36-37). The growth in subprime lending slowed in 1999 and turned negative in 2000 before resuming its strong growth in 2001(Chomsisengphet and Pennington-Cross, p.41). In this second stage of growth (Figure 1) from 2001 through 2003, the quality of the subprime loans as measured by grade and average credit scores increased (Chomsisengphet and Pennington-Cross, pp 43-44). During the 2001-2003 period lenders appear to have been influenced by the fallout and effects of the subprime auto crisis, since loan quality improved significantly.

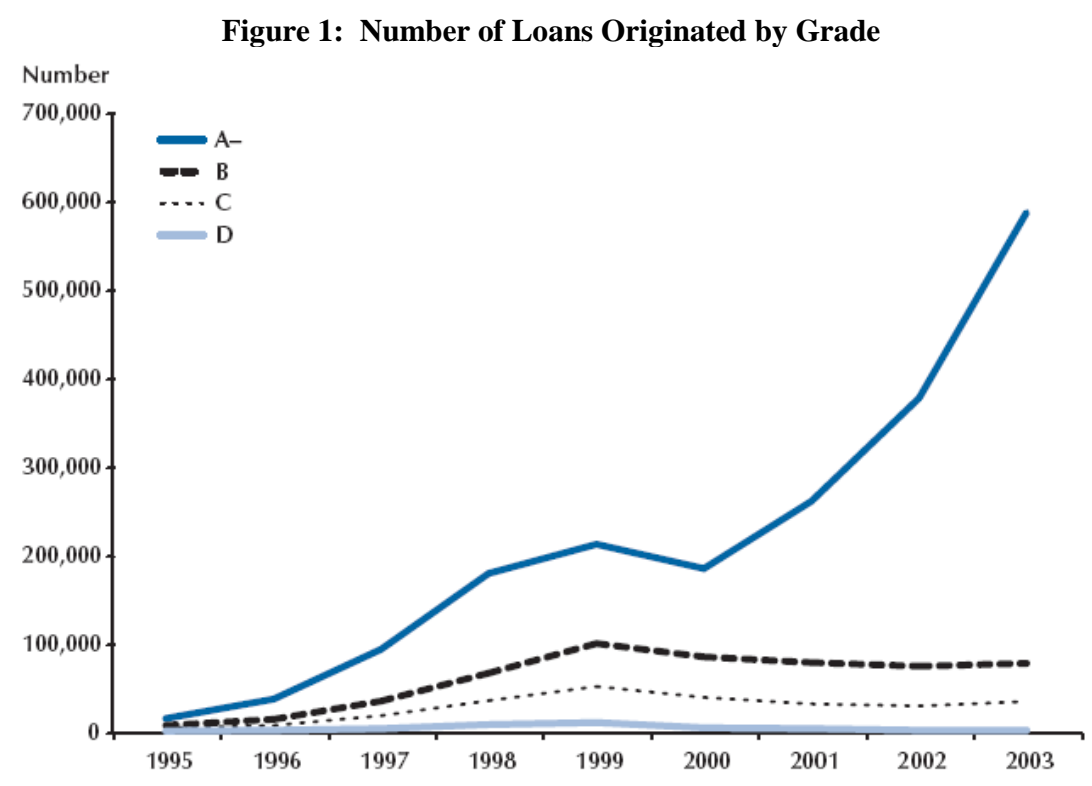

Source: Chomsisengphet, Souphala and Anthony Pennington-Cross. "The Evolution of the Subprime Mortgage Market." Federal Reserve Bank of St. Louis Review. Jan/Feb 2006.

Beginning in 2004, as shown in Figure 2, subprime loan origination growth grew significantly. By 2005, subprime originations had risen to $\$ 625$ billion and by $200614 \%$ of the total mortgage stock was subprime (Gramlich, p.6). The current rise in loan default rates suggests that this increase in subprime loan origination related to a decline in loan quality, as shown in Figure 3. 
Figure 2

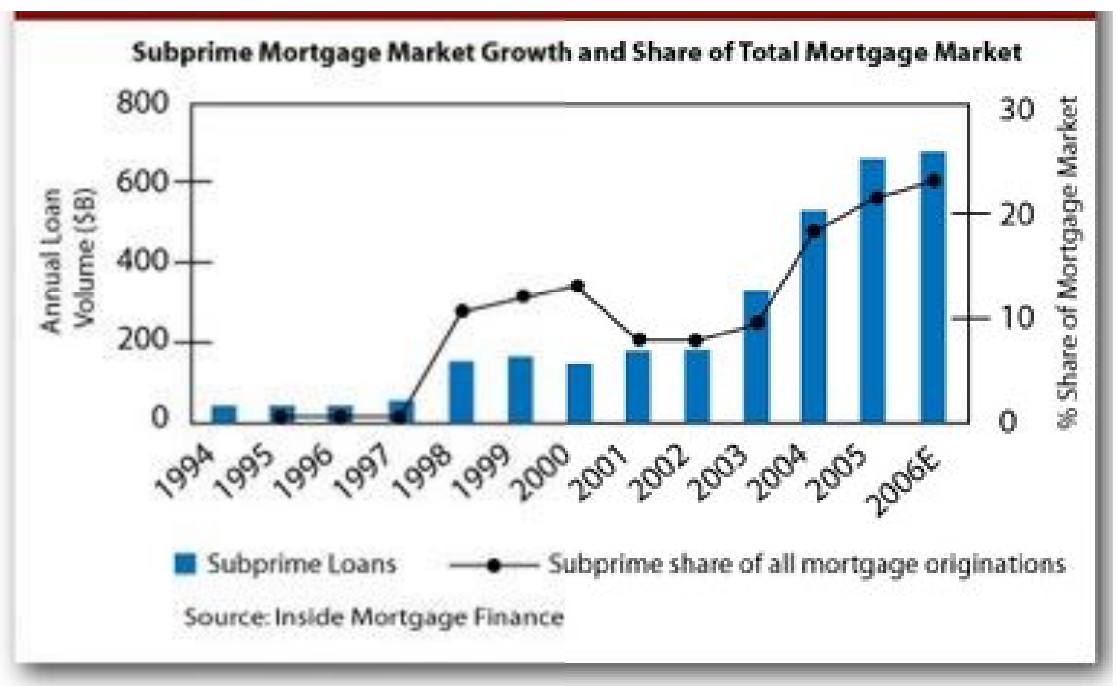

Figure 3: Mortgage Delinquency Rates, 2001-07 (percent)

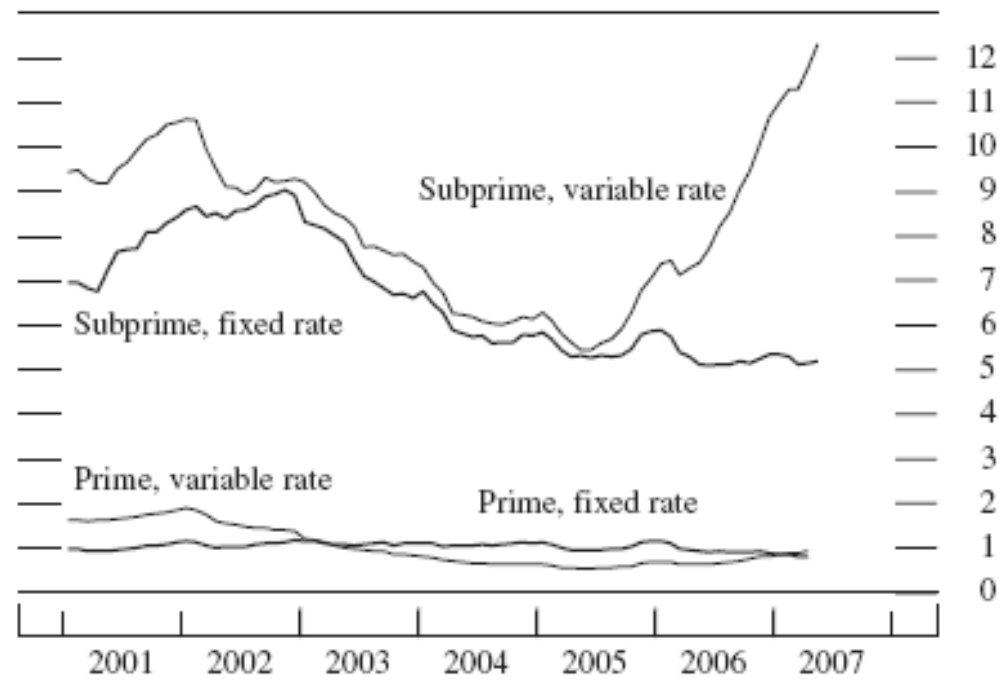

NOTE: The data are monthly. Prime-mortgage data extend through April 2007, and subprime-mortgage data extend through May 2007. Delinquency rate is the percent of loans ninety days or more past due or in foreclosure. Prime mortgages include nearprime mortgages.

Source: Board of Governors of the Federal Reserve System. Monetary Policy Report to the Congress. July 18, 2007.

\section{The Subprime Mortgage Market Grows}

Many of the same underlying forces that fed the tremendous growth in the subprime auto lending market helped to grow the subprime mortgage market. Again, we find a change in lender attitude, technological advances, regulatory changes and neglect, historically low interest rates, and Wall Street financing. However, this boom was fueled even further by rapidly rising housing prices, something that did not happen with automobiles, and the creative invention of financing vehicles such as CDOs. 
Mortgage lenders became willing to lend to borrowers with poorer credit, attracted by higher interest rates, points, fees and prepayment penalties at a time when interest rates were at historical lows. In addition, the lenders believed that the risk was minimal since rising house prices would increase their security position. Buyers, seeing the equity in their homes growing rapidly, had a ready source of further borrowing. The Federal Reserve Bank of Atlanta estimated that the availability of new mortgage options accounted for a greater proportion of the increase in home ownership than did demographic changes (Gramlich, p.7).

Technological and regulatory developments beginning in the 1980s also enabled subprime mortgage growth. The Depository Institutions Deregulation and Monetary Control Act of 1980 effectively abolished usury ceilings on first-lien mortgages and thus paved the way for the higher cost subprime mortgages (Gramlich, p.4). The Tax Reform Act of 1986 also stimulated the growth by prohibiting the deduction of interest on consumer loans for income tax purposes, thereby encouraging homeowners to borrow on their equity as an alternative to the traditional consumer loan (Chomsisengphet and Pennington-Cross, p.38). Paralleling the subprime auto lending markets, significant technological refinements such as automated scoring models aided lenders in rapidly approving mortgage applications.

Economic conditions also contributed to the growth of the subprime market. The less frequent and severe recessions that resulted in relatively stable employment rates allowed lenders to believe that borrowers would not have difficulty repaying their loans and the risk of default was minimal. Another important factor was the lower interest rates produced by inflation dampening policies during the 1980s and 1990s (Gramlich, p.5). Spurred on to mitigate the effects of the 2001 recession, the Federal Reserve lowered short-term interest rates and kept them at these levels through 2004. These low interest rates made it possible for individuals to finance even larger amounts of borrowing and refinancing became a major activity (Eavis, p.120). The huge demand produced by all this cheap money pushed real estate prices up at very rapid rates. This was a gold rush and no wanted to be left behind (Mozilo, p. 33).

As in the previous subprime crisis, Wall Street played a significant role in fostering the growth of the subprime mortgage market. Gramlich states that, "the influence of capital markets has played a significant role in the development of the subprime mortgage market. Fannie Mae and Freddie Mac, huge secondary market mortgage entities, began securitizing prime mortgages in the 1970s. By the 1990s, private Wall Street markets were doing it in the subprime market, introducing huge new sources of capital and financing largely unsupervised subprime mortgage lenders." (Gramlich, p.5). Figure 4 shows the growth of mortgage-backed securities within the mortgage market.

Collateralized debt obligations, CDOs, were perhaps the most influential securitization instruments in the subprime mortgage lending market. Originators packaged a variety of mortgages in a pool and produced a series of tranches with ratings running from AAA to BBB and lower (Todaro interview). This was a level of financial creativity that was not approached in the subprime auto market, and it may well be the biggest single factor in creating the current crisis.

All of the demand led to tremendous growth in the number of mortgage brokers. Independent mortgage brokers were attracted by the high fees from originations and were especially active in areas such as minority communities underserved by old-line commercial banks and thrifts (Gramlich, p. 19). In addition, many traditional lenders established mortgage affiliates that were subject to less regulation and restrictions (Lubove and Taub, p.42). In 1987 an estimated 7,000 broker firms served the market place, by 2004 the number was estimated at 53,000 (Lubove and Taub, p. 43). Here, again, is an interesting parallel. In the auto loan market, the dealers were originating the loans; in the mortgage loan market, the brokers were originating them. Neither group actually lent the money. 
Figure 4: MBS Share of Total Mortgage Debt Outstanding

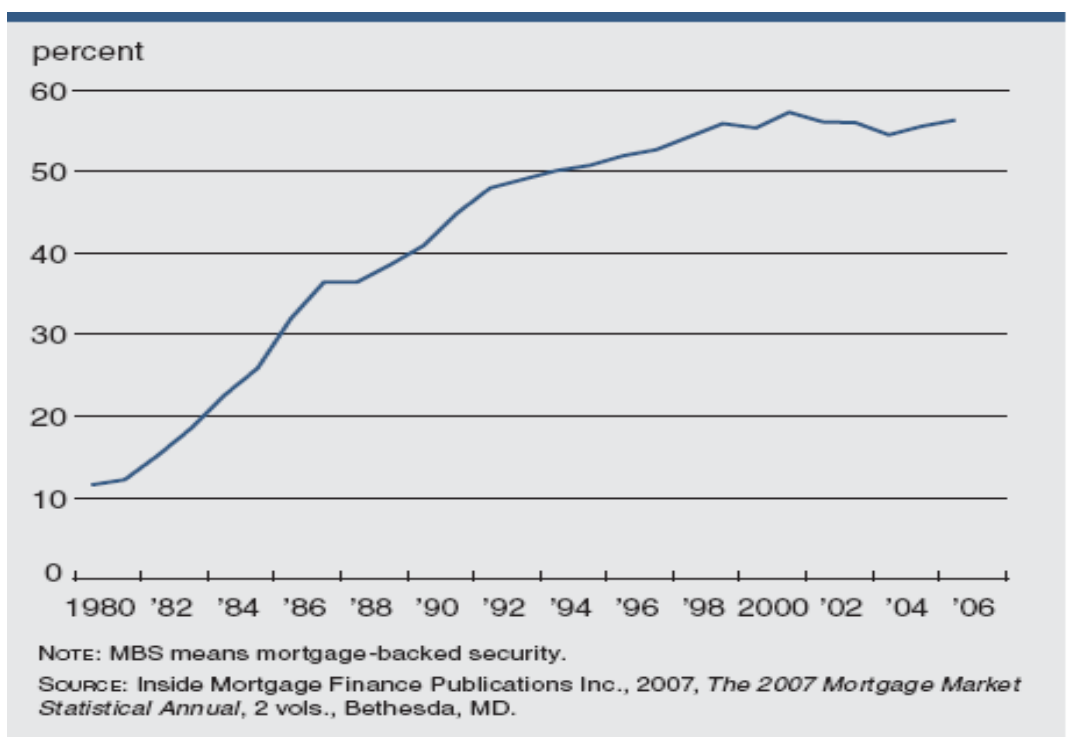

Like the auto loan market, at first lending in the subprime mortgage market was fairly sensible. But by 2005, lenders abandoned their traditional underwriting standards (Coy, p. 34) and creative new lending practices mushroomed. Products included teaser rate adjustable rate mortgages, option payment mortgages, piggy-backed or second-lien mortgages, and no-documentation loans (Bender, p. 35). By far the most popular instruments were the adjustable-rate mortgages. Nearly $80 \%$ of all securitized subprime loans were ARMs by early 2006 . The teaser-rate $2 / 28$ and $3 / 27$ loans that provide a low initial fixed rate for the first two or three years, then changing to an adjustable rate for the remaining 28 or 27 years were very popular; especially when the buyer wanted to flip the house (Bender, p.35). The pay-option ARM permitted the borrower to pay less than the interest due each month adding the unpaid amount to the principal and resulting in negative amortization (Coy, p. 14). "Liar loans", so named because of the lack of verification of income or savings, only added fuel to the fire.

As we saw in the subprime auto loan market, unethical and illegal practices by loan originators furthered the problems. Brokers falsified borrower's financial records, over-stated income, and made temporary deposits in a borrower's account to inflate assets, just to mention a few activities (Lubove and Taub, p. 42). Taher Afghani, who worked for a mortgage broker in California, describes an atmosphere reminiscent of the movie about high-pressure stockbrokers, Boiler Room, that came out in the year 2000. He and fellow brokers dispensed with details about rates and fees and instead talked up how borrowers could use home equity loans to pay down other debts. "It was easier than financing a car" (Lubove and Taub, p. 44).

Mirroring the subprime auto loan crisis, risk in the subprime mortgage market was difficult to assess. Without enough historical performance related to exotic adjustable-rate loans, predictions of losses were highly unsubstantiated (Farzad, Goldstein, Henry and Palmeri, p. 32). Although ratings agencies attached ratings to the mortgage backed obligations, questions are now being raised about how reliable these ratings were. Unlike the auto loan experience, the complexity of the instruments rose to unprecedented levels. Bruce Wasserstein, CEO of Lazard, believes that through securitization, risk spread to people who were not quite sure what they were getting, and the lack of transparency permitted the piling of risk upon risk (Bianco, p.40).

\section{The Subprime Mortgage Lending Market Collapses}

By the end of 2005, the era of low interest rates was over and they were on an upward path. In addition, the real estate market started to collapse and delinquencies on mortgages were rising (Figure3). Initially, the 
markets shrugged off the warning signs. In February of 2007, HSBC Bank reported a loss of $\$ 1.8$ billion on its mortgage portfolio but the markets hardly noticed (Tully, p. 55).

As delinquencies rose, foreclosures began increasing. Borrowers found that they had little, no, or even negative equity in their properties. Rather than struggle to make the payments, they simply walked away. Other borrowers became aware that their teaser rates were ending, producing a significant increase in their monthly payments that they could not afford. The income they expected to have or that the mortgage brokers imagined they would have was not there, and they could not afford their properties. It is well to recall that many of the subprime borrowers fall into two groups: those who own and occupy their properties and those who hold them for investment or speculation purposes. Clearly, it is easier for the latter group to abandon their properties.

The extent of the subprime mortgage market also began to emerge. Moody's reported in March 2007 that ,on average, 45\% of the contents of U.S. CDOs sold in 2006 consisted of subprime home loans (Tomlinson, Richard, and Evans, pp. 50-52).

The crisis of confidence in mortgage-backed securities spread quickly. For Buffalo based M \& T Bank, the problems began in March 2007. As they bundled $\$ 800$ million of subprime loans and brought them to the Wall Street financial markets for sale, there was only one distressed purchase bid on the package. The bank refused to sell the mortgages and put them in their own portfolio (Hummel interview).

Prices for subprime mortgage bonds and mortgage CDO's subsequently lost $5 \%$ to $60 \%$ of their value from February through October 2007, with much of the decline taking place over the summer after investor demand had dried up (Smith). During this same time period, bond managers unloaded subprime mortgage bonds and sought safety in U.S. Treasuries. This flight to quality drove the junk bonds' yield premium over Treasuries to 300 basis points on July 11 from 240 basis points on June 5, the fastest increase since April 2005 (Pittman and Salas, p.15).

Just as in the subprime auto crisis, mortgage lenders realized that without access to the debt markets they could not originate new loans and without new loans they could not generate income. Consequently, many finance companies and independent brokers closed, went bankrupt or were acquired.

Unlike the subprime auto market, investment bankers were profoundly affected by the collapse of the subprime mortgage market. Bear Stearns, Merrill Lunch and Lehman Brothers all had significant interests in this market. On October 24, 2007, Merrill Lynch announced a stunning \$7.9 billion in losses as a result of subprime loans. Merrill had taken a leadership role in underwriting CDOs in 2006 and 2007, a time when subprime mortgage lenders all but threw lending standards out the window. Over that period, Merrill was the lead underwriter on 136 CDO deals with a dollar value of $\$ 93$ billion (Goldstein, p. 32). By January of 2008, Merrill Lynch's loss estimate had climbed to $\$ 15$ billion (Large Loan Losses at Merrill Lynch) and by September of 2008 they were being acquired by Bank of America (Mollenkamp, Craig and Ng). Bear Stearns, the prestigious investment banking firm, was sold to J.P. Morgan at fire sale prices after their losses in the subprime mortgage market consumed their capital (Sidel, Berman and Kelly), and Lehman Brothers was in bankruptcy with parts of it being sold to Barclays Bank (Craig, McCracken, Hilsenrath and Solomon), and this was only the tip of the iceberg. The U.S. government had to take over Freddie Mac and Fannie Mae (Hagerty, Simon and Paletta). Despite these efforts, the financial markets remained in turmoil. On Friday, September 12, 2008 the Dow Jones Industrial Average closed at 11,421.99 and by Wednesday, September 17, 2008 it had dropped over 800 points or $7 \%$ ! By that time the U.S. Treasury had arranged to invest up to $\$ 85$ billion in insurance giant AIG, the world credit markets were virtually locked up with borrowing costs doubling for the most creditworthy borrowers, and the two remaining investment banks, Goldman Sachs and Morgan Stanley, were under great pressure (Lauricella, Rappaport and Lobb). It took the announcement of the greatest financial rescue by the U.S. government since the 1930's on Thursday, September 18, 2008 to restore some semblance of order to the markets (Solomon, Scannell, Zukerman and Paletta).

There is plenty of blame to go around in this latest crisis. Wall Street investment banks fueled the growth of subprime lending and invented complex instruments to raise the capital needed by the mortgage brokers. The mortgage brokers made the loans and encouraged many to borrow who could not afford to do so. They became 
especially culpable beginning in 2005 , when lending standards were readily abandoned in the pursuit of profits (Coy, p.34). Rating agencies either failed to understand the true risks of subprime mortgages or allowed conflicting interests from the fees they charge to cloud their judgments. Moreover, when the ratings downgrades came in July of 2007, many argue that they were too small and too late (Benner and Lashinsky, pp.45-46). Hedge funds and international investors hungrily consumed securitized subprime debt. From Chinese banks to Dutch insurance companies, foreign investors tended to buy the paper with the highest ratings (Tully, p.54). Hedge funds took the lower rated, higher yielding debt and they leveraged the returns by buying on margin, producing returns of $20 \%$ or more for their investors (Tully, p. 55). Home appraisers were encouraged to give inflated appraisals to make the loans work (Hummel interview). In November 2007, New York Attorney General Andrew Cuomo began investigating Washington Mutual over allegations of improper home appraiser/broker relationships (Menchaca). Finally, home buyers and most especially speculators must bear part of the blame. While some buyers may have been duped into borrowing too much money, others had to clearly know what they were doing. With the falling real estate market many subprime borrowers will pay dearly for their poor judgment - losing their houses and having their credit ruined (Eavis, p.120).

\section{CONCLUSIONS}

The collapse of the subprime mortgage market has dwarfed the subprime auto crisis and arguably has become one of the largest problems affecting both the U.S. and world economy for a number of years. It has pushed the U.S. economy into a recession or a near recession, taken billions of dollars off the values of the securities markets, resulted in the failure of many venerable Wall Street firms, and has generated a massive government bailout. Homeowner equity has fallen precipitously and last year, for the first time, American homeowners owned less than half the value of their houses (Reddy and Murray). It will be a long time before these effects are unwound.

Individuals like Angelo Mozilo, of Countrywide, and Stanley O’Neil, formerly of Merrill Lynch, have contended that no one fully understood the risks of subprime lending. That is too easy an answer. The lessons of the subprime auto market clearly should have shown that when established risk management practices and basic notions of common sense are abandoned, disaster will follow. Markets do not continually rise and bubbles do burst.

Like the crisis that led to Sarbanes Oxley, the government is now considering a series of reforms along with its rescue efforts. Will all of this be enough to prevent another disaster? Only history will reveal the answer to that question, but past experience suggests that the answer is no.

\section{AUTHOR INFORMATION}

Jared E. Hojnacki is a Finance and Honors Program graduate of Canisius College where he received his Bachelor of Science in Business Administration Degree in 2007. This paper is based on his thesis for the Honors Program. Mr. Hojnacki is currently working as a Consultant I for Bates White, LLC in Washington, DC

Richard A. Shick is a Professor of Finance in the Richard J. Wehle School of Business at Canisius College. He is the author of more than 25 scholarly publications in various areas of Finance including Corporate Finance, Investments, and Financial Institutions. In addition, he has published work on the valuation of assets for divorces and assessment of student satisfaction with educational programs. Dr. Shick was also a consultant for the Office of the Comptroller of the Currency.

\section{REFERENCES}

1. Adams, William, Liran Einav, Jonathan Levin, Liquidity constraints and imperfect Information in subprime lending, Cambridge, MA: National Bureau of Economic Research, 2007.

2. Adamson, Joseph, and Todd J. Zywicki, "Subprime Mortgage Lending," Regulation, Summer 2007, Vol. 30, Issue 2, 5-6.

3. $\quad$ Anders, George, "Countrywide Finds No. 1 Spot Isn't Easy," The Wall Street Journal, 5 Sept. 2007: A2.

4. $\quad$ Anders, George, "Mortgage Lenders Lack Salvage Skills," The Wall Street Journal, 19 Sept. 2007: A2. 
5. Mozilo, Angelo, Interview with Maria Bartiromo, Business Week, 10 Sept. 2007: 29+.

6. Bender, Matthew, Subprime lending: an update of the issues and approaches, Newark, NJ: LexisNexis, 2007.

7. $\quad$ Benner, Katie, and Adam Lashinsky, "Subprime Contagion?" Fortune, 23 Jul. 2007: 45-46.

8. $\quad$ Benner, Katie, "Why We Need CSI: Wall Street," Fortune, 3 Sept. 2007: 54.

9. Bianco, Anthony, “"Expect Lots More Embarrassment,” Business Week, 3 Sept. 2007:40+.

10. Board of Governors of the Federal Reserve System, Monetary Policy Report to the Congress, July 18, 2007.

11. Brickley, Peg, "Lender's Troubles Threaten Thousands of Homeowners," The Wall Street Journal, 12 Sept. 2007: A15.

12. Chappell, Lindsay, "The lure of the subprime: tackling customers with poor credit is a risky business - with a wealth of promise," Automotive News, 12 Aug. 1996.

13. Chomsisengphet, Souphala, and Anthony, Pennington-Cross, "The Evolution of the Subprime Mortgage Market," Federal Reserve Bank of St. Louis Review Jan.-Feb. 2006, Vol. 88 Issue 1, 31-56.

14. Connelly, Mary. "Digging deeper: automobile dealers offering financing to customers with poor credit histories - 1997 Trends," Automotive News, 27 Jan. 1997.

15. "Consumer Finance: The Credit Goes to the Consumer," Solomon Brothers Global Equity Research, Sept 1997.

16. Cooper, James C., "Housing's New Risks for the Economy," Business Week, 9 \& 16 Jul. 2007: 21-22.

17. Coy, Peter, "The Housing Bust's Latest Blow," Business Week, 5 Nov. 2007: 34.

18. Coy, Peter, "In Praise of a 'Toxic' Loan,” Business Week, 8 Oct. 2007: 14.

19. Craig, Susanne, Jeffrey McCracken, John Hilsenrath and Deborah Solomon, "AIG, Lehman Shock Hits World Markets," The Wall Street Journal, 16 Sept. 2008: A1, A2.

20. $\quad$ Eavis, Peter, “Oh, the People You'll Blame!” Fortune, 17 Sept. 2007: 118+.

21. Edwards, Andrew, "S\&P's Subprime Report Sees Pain, Hope Ahead," The Wall Street Journal, 14 March 2008: A15.

22. Elul, Ronel, "The Economics of Asset Securitization," Business Review of the Federal Reserve Bank of Philadelphia, 3Q, 2005: 16-25.

23. Farzad, Roben, Matthew Goldstein, David Henry, and Christopher Palmeri, "Not So Smart," Business Week, 3 Sept. 2007: 30+.

24. $\quad$ Farzad, Roben, "Dude, Where’s My Bailout?” Business Week, 10 Sept. 2007: 34.

25. Farzad, Roben, "Let the Blame Begin," Business Week, 6 Aug. 2007: 32+.

26. Goldstein, Matthew, "Did Bear Stearns Soft-Pedal the Risks?" Business Week, 24 Sept. 2007: 38+.

27. Goldstein, Matthew, "Why Merrill Got Burned So Badly," Business Week, 5 Nov 2007:32.

28. Goldstein, Matthew, and David Henry, "The Pain Moves Beyond Subprime," BusinessWeek, 13 Aug. 2007: 35-37.

29. Goldstein, Matthew, David Henry, and Mara Der Hovanesian, "Mutually Assured Mayhem," Business Week, 9 \& 16 Jul. 2007: 26+.

30. Gramlich, Edward M., Subprime mortgages: America's latest boom and bust,_Washington, D.C.: Urban Institute Press, 2007.

31. Hagerty, James R., "Credit’s Crunch Harder on Some,” The Wall Street Journal, 1-2 Sept. 2007: A2

32. Hagerty, James R., and Karen Richardson, "Countrywide Continues Slide, Leaving Questions of Value," The Wall Street Journal, 29 Aug. 2007: C1+.

33. Hagerty, James R., Ruth Simon and Damian Paletta, "U.S. Seizes Mortgage Giants," The Wall Street Journal, 8 Sept. 2008: A1, A15.

34. Hagerty, James R., and Lingling Wei, "Countrywide Seeks More Deposits to Finance Mortgage Lending," The Wall Street Journal, 19 Sept. 2007: C5.

35. Hagerty, James R., and Michael Corkery, "Investors Default on Outsize Share of Home Loans," The Wall Street Journal, 31 Aug. 2007: A1+.

36. Hagerty, James R., Kara Scannell, and Sarah Lueck, “Congress Takes Up Mortgages,” The Wall Street Journal, 6 Sept. 2007: A8.

37. Henry, David, and Matthew Goldstein, “It's Just Going to Get Worse,” Business Week, 23 Jul. 2007: 29.

38. Henry, David, “Anatomy of Ratings Downgrade,” Business Week, 1 Oct. 2007: 66-67. 
39. Henry, Jim, "Subprime lender on brink of bankruptcy," Automotive News 14 Jul. 1997.

40. Henry, Jim, "Subprime survivors prosper; Industry is stronger after the shakeout," Automotive News, 25 Sept. 2000.

41. Henry, Jim, "Shrinking Field: Remaining Subprime Lenders Celebrate Surviving Industry Meltdown," Automotive News, 22 Mar. 1999.

42. Hughlett, Mike, "'Subprime' Loan Risks Bring Rewards to Norwest," KnightRidder/Tribune Business News, 27 Jun. 1997.

43. Hummel, Evan, Personal interview, 21 Oct. 2007.

44. Ip, Greg, and Deborah Solomon, "Fed Chief Cites Subprime Culprit," The Wall Street Journal, 21 Sept. 2007: A2.

45. I Ip, Greg, "Lenders Urged to Help Avoid Foreclosures," The Wall Street Journal, 5 Sept. 2007: A4.

46. Ip Greg, "Fed Offers Lifeline for Spurned Debt," The Wall Street Journal, 12 March 2008: A1, A17.

47. Kendall, Leon T., and Michael J. Fishman, A Primer on securitization, Cambridge, MA: MIT Press, 1996.

48. Kim, Jane J, “Credit Crunch Moves Beyond Mortgages,” The Wall Street Journal, 22 Aug. 2007: D1+.

49. Lakhbir, Hayre, Salomon Smith Barney guide to mortgage-backed and asset-backed securities, New York, NY: John Wiley, 2001.

50. “Large Loan Losses at Merrill Lynch,” 123jump.com., January 17, 2008.

51. Lauricella, Tom, Liz Rappaport, and Annelena Lobb, "Mounting Fears Pummel World Markets As Banking Giants Rush to Find Buyers," The Wall Street Journal, 18 Sept. 2008: A1, A2.

52. Lawson, James C. "Start your engines! Banks, independent finance companies vie for auto finance market," US Banker, 1 Jul. 1995.

53. "Lender Foss reflects on a risky business," Automotive News, 27 Dec. 1999.

54. Long, Matthew, "Financial Security Assurance Inc., v. CSC Logic/MSA, LLP D/B/A Loan Servicing Enterprise," Expert Report of Matthew Long, 14 May 2004.

55. Lubove, Seth, and Daniel Taub, "The Subprime Sinkhole," Bloomberg, Jul. 2007: 36+.

56. Lucchetti, Aaron, and Kara Scannell, "Ratings Firms: A Dollar Short and Day Late?" The Wall Street Journal, 26 Sept. 2007: C1+.

57. Lucchetti, Aaron, "Ratings Firms' Practices Get Rated," The Wall Street Journal, 7 Sept. 2007: C1+.

58. Mehring, James, "Where Home Prices Drop, Malaise Follows," Business Week, 20 \& 27 Aug. 2007: 26.

59. Menchaca, Paul, "WaMu Under Appraisal Fraud Probe," Asset Securitization Report, 19 Nov. 2007.

60. Mincer, Jilian, "Lenders Require Higher Credit Scores," The Wall Street Journal, 25 Sept. 2007: D3.

61. Mollenkamp, Carrick, Susanne Craig and Serena Ng, "Crisis on Wall Street as Lehman Totters, Merrill Seeks Buyer, AIG Hunts for Cash,” The Wall Street Journal,15 Sept. 2008: A1, 18.

62. "Nonprime auto lending: high risk, high opportunity or both?" ABA Banking Journal, 1 June 1997, Part 3.

63. Paletta, Damian, "Limits on Fannie, Freddie Could Be Lifted," The Wall Street Journal, 22-23 Sept. 2007: A4.

64. Paletta, Damian, "U.S. to Revamp Credit Rules, Drawing From Crisis Lessons," The Wall Street Journal, 13 March 2008: A1, A16.

65. Pavel, Christine, Securitization: the analysis and development of the loan-based asset backed securities markets, Chicago, IL: Probus Pub. Co., 1989.

66. Pittman, Mark, and Caroline Salas, "The Reckoning," Bloomberg, Sept. 2007: 14-15.

67. Quinn, Lawrence Richter, "The buying up of subprime,” Mortgage Banking, 1 Apr. 1998.

68. Range, Jackie, and Andrew Morse, "Credit Turmoil May Ignite Spree of Overseas Deals by Asian Firms," The Wall Street Journal, 29 Aug. 2007: C4.

69. Reddy, Sudeep, and Michael Corkery, "Housing Chill Grows Worse, Bites Consumers," The Wall Street Journal, 26 Sept. 2007: A1+.

70. Reddy, Sudeep, "Likelihood of a Recession Is Given Better Odds," The Wall Street Journal, 13 Sept. 2007: A5.

71. Reddy, Sudeep and Sara Murray, "Housing, Bank Troubles Deepen," The Wall Street Journal, 7 March 2008: A1, A15.

72. Robert Lawrence Kuhn, Mortgage and Asset Securitization, Homewood, IL: Dow Jones-Irwin, 1990.

73. Roeder, David, "FBI takes Mercury Finance files: Lender names new chief executive," Chicago Sun-Times, 4 Feb. 1997. 
74. Scannell, Kara, and Deborah Solomon, "Unraveling the Subprime Mess," The Wall Street Journal, 4 Sept. 2007: A6.

75. Schroeder, Robert, and Aaron Lucchetti, "Credit Raters Face Heat; Moody's Is Sued by a Fund,” The Wall Street Journal, 27 Sept. 2007: C3.

76. Sidel, Robin, Dennis K. Berman, and Kate Kelly, "J.P. Morgan Rescues Bear Stearns," The Wall Street Journal, 17 March 2008: A1, A12.

77. Sloan, Allan, "On the Brink of Disaster," Fortune, 16 Apr. 2008: 78-84.

78. Smith, Randall, “Merrill's \$5 Billion Bath Bares Deeper Divide,” The Wall Street Journal, 6 Oct. 2007.

79. Solomon, Deborah, Kara Scannell, Gregory Zukerman and Damian Paletta, "U.S. Mulls Plan to Clean Up Finance System As Part of Widening Effort to Stem Crisis,” The Wall Street Journal, 19 Sept. 2007: A1, A10.

80. Stein, Ben, "Tales of the Crash of 2007," Fortune, 17 Sept. 2007: 208.

81. Streeter, William W., "Subprime, whose responsibility?” ABA Banking Journal, Jun. 2007, Vol. 99 Issue 6, 4.

82. Sweet, Ken, “Government Seizes Fannie Mae, Freddie Mac,” FOXBusiness.com, 7 Sept. 2008.

83. "Three Trends Are Reshaping Auto Finance," ABA Banking Journal, 1 Feb. 1997, Part 1.

84. Todaro, Michael, Personal interview, 19 Oct. 2007.

85. Tomlinson, Richard, and David Evans, "The Ratings,” Bloomberg, Jul. 2007: 50+.

86. Tully, Shawn, "Risk Returns With a Vengeance," Fortune, 3 Sept. 2007: 51-56.

87. Tully, Shawn, "Why the Private Equity Bubble is Bursting," Fortune, 20 Aug. 2007: 30+.

88. "Update on the Subprime Mortgage Market," Western Asset, Jul. 2007.

89. Wessel, David, "Banks' New Credit Austerity to Help Set Economy's Path," The Wall Street Journal, 13 Sept. 2007: A2.

90. Willis-Boyland, Anita, "Riding Herd on Subprime,” Mortgage Banking, 1 May 1997. 